\title{
Synthesis of a spiroacetal intermediate for the synthesis of the anti- Helicobacter pylori agent CJ-12, 954
}

\author{
Margaret A. Brimble,* Christina J. Funnell, Stephen Gorsuch, and Matthew Sidford \\ Department of Chemistry, University of Auckland, Private Bag 92019, Auckland, New Zealand \\ E-mail: m.brimble@auckland.ac.nz
}

(received 13 Sep 01; accepted 28 Oct 01; published on the web 05 Nov 01)

\begin{abstract}
A method has been established for the synthesis of the 5,5-spiroacetal moiety of the antiHelicobacter pylori agents CJ-12,954 1 and CJ-13,014 2 in racemic form and as a mixture of stereoisomers. Retrosynthetically the key spiroacetal $\mathbf{9}$ is derived from the acyclic protected dihydroxyketone precursor 10 or $\mathbf{1 1}$ which in turn are available from enynone 25 or 26. Enynones 25 and $\mathbf{2 6}$ were prepared via addition of the acetylide derived from acetylenes 13 or 14 to aldehyde 12 followed by oxidation of the resultant alcohols 23 and 24 respectively. Acetylenes 13 and 14 in turn were available via [2,3]-sigmatropic rearrangement of allyl propargyl ether 16. Extension of this reaction in an asymmetric sense by use of a chiral base would have provided acetylene $\mathbf{1 4}$ in enantioenriched form, however, efforts towards this end were disappointing. Enynones $\mathbf{2 5}$ and $\mathbf{2 6}$ were converted to keto epoxides $\mathbf{1 0}$ and $\mathbf{1 1}$ respectively by treatment with meta-chloroperbenzoic acid followed by hydrogenation of the acetylene. Attempts to effect deprotection and cyclization of bis-silyl ethers $\mathbf{1 0}$ and $\mathbf{1 1}$ to spiroacetal $\mathbf{9}$ were complicated by the presence of the epoxide. In an alternative approach enynone 26 was converted to methyl acetal 29 upon treatment with camphorsulfonic acid in methanol. Subsequent epoxidation of the terminal alkene 29 afforded epoxide $\mathbf{3 0}$ which then underwent smooth hydrogenation and cyclization in situ to the desired spiroacetal $\mathbf{9}$.
\end{abstract}

Keywords: Spiroacetals, anti-ulcer agents, Helicobacter pylori, Wittig rearrangement, antibiotic CJ-12,954

\section{Introduction}

Gastric and duodenal ulcers affect a significant portion of the human population worldwide. Initially they were thought to be caused by damage to stomach and duodenal tissue by digestive fluids (acid and pepsin). More recent studies have shown a relationship between the presence of the microaerophilic Gram-negative bacterium Helicobacter pylori, which appears to live beneath the mucus layer of the stomach, and gastric and duodenal ulcers. ${ }^{1}$ Therapy to eliminate Helicobacter pylori from the gastroduodenal tract would remove the root cause of gastric and duodenal ulcers therefore antibiotics are prescribed for the treatment of Helicobacter pylori in addition to treatment aimed at decreasing the production of stomach acid. ${ }^{2}$ 
In a screening program designed to discover such compounds from microbial secondary metabolites, seven new phthalide compounds 1-7 with anti-Helicobacter pylori activity were isolated from the basidiomycete Phanerochaete velutina CL6387. ${ }^{3}$ The two most potent compounds, CJ-12, 9541 and CJ-13, 0142 have MICs of $5 \mathrm{ng} / \mathrm{ml}$ establishing that the presence of a spiro acetal moiety in addition to a phthalide unit enhances biological activity. The phthalide compounds 1-7 were specific for Helicobacter pylori in that they did not show antibacterial activities when tested against a panel of other microorganisms. This observed specific activity against Helicobacter pylori suggests that phthalides 1-7 may exhibit less side effects caused by disturbance of the normal gastro-intestinal microbial flora and may not induce drug resistance of non-target micro organisms.

The phthalides 1-7 are related to spirolaxine and sporotriacale $^{4}$ which have also been reported to have cholesterol lowering activity. ${ }^{5}$ Spirolaxine has helicobactericidal activity similar to 1 and 2. The rare 5,5-spiroacetal found in CJ-12, 9541 and CJ-13,014 2 is also present in an insect pheromone ${ }^{6}$ and in a constituent of hop oil. ${ }^{7}$ We herein report a synthesis of the 5,5spiroacetal moiety of the anti-Helicobacter pylori agents CJ-12,954 and 1 and CJ-13,014 2.
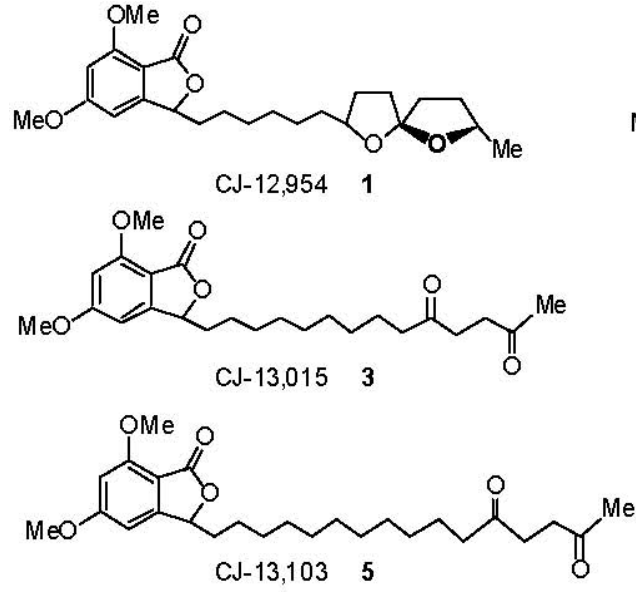

CJ-13,103 5
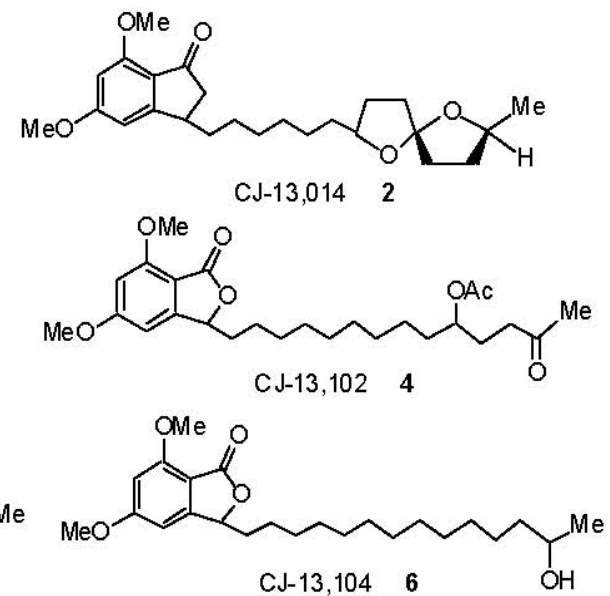

CJ-13,104 6

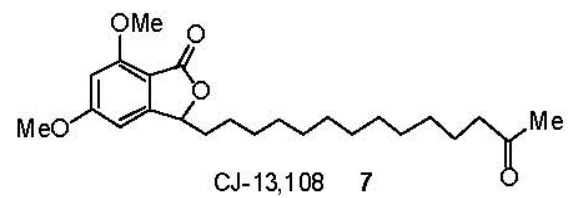

\section{Results and Discussion}

The stereochemistry of the stereogenic centre on the phthalide ring in both CJ-12,954 1 and CJ13,014 2 has not been defined to date. CJ-12,954 1 and CJ-13,014 2 both exhibit 2S,7S stereochemistry in the spiroacetal ring and only differ in the configuration of the spirocentre. The focus of this work was on the development of a synthetic route to the spiroacetal moiety of CJ12, 9541 and CJ-13,014 2 as a mixture of stereoisomers using a synthesis that could be adapted at a later stage to control the stereochemistry at C-2 and C-7 of the spiroacetal ring system.

The key step in the retro synthesis adopted for the synthesis of CJ-12,954 1 and CJ-13,014 2 
(Scheme 1) hinges on the addition of the Grignard reagent derived from bromide 8 to spiro acetal epoxide 9 followed by deoxygenation of the resultant secondary alcohol. The acyclic protected dihydroxy ketone precursor $\mathbf{1 0}$ or $\mathbf{1 1}$ to spiro acetal epoxide $\mathbf{9}$ is then constructed from addition of the acetylide of acetylene $\mathbf{1 3}$ or $\mathbf{1 4}$ to aldehyde $\mathbf{1 2}$.

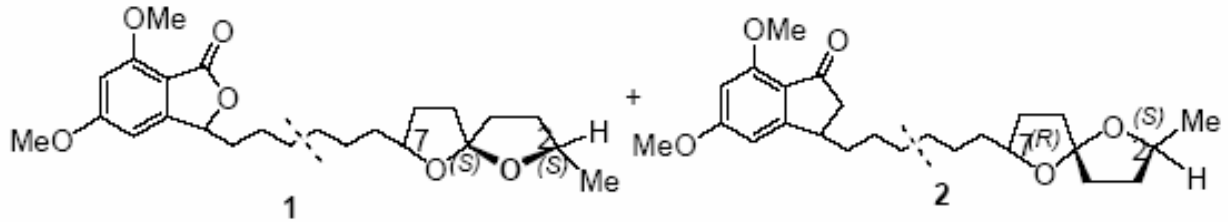

$\Downarrow$

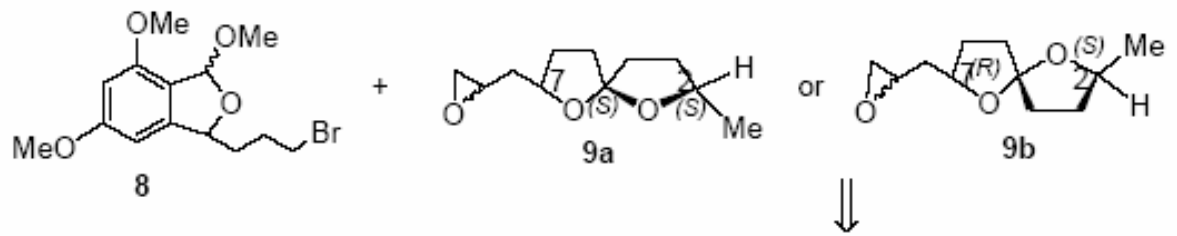

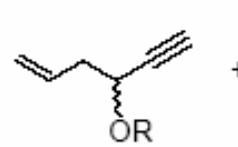

$13 \mathrm{R}=\mathrm{Si}^{t} \mathrm{BuPh}_{2}$ $14 \mathrm{R}=\mathrm{Si}^{\mathrm{t}} \mathrm{BuM \textrm {H } _ { 2 }}$

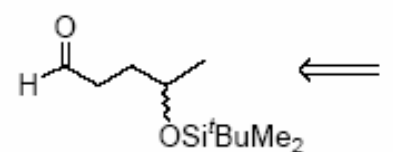

12

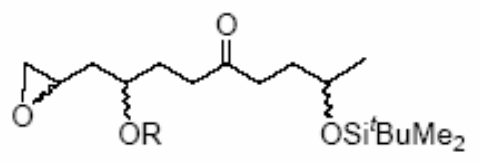

$10 \mathrm{R}=\mathrm{Si}^{\mathrm{t} B \mathrm{Bu} \mathrm{P}_{2}}$

$11 \mathrm{R}=\mathrm{Si}^{\mathrm{t} B u M \mathrm{~B}_{2}}$

\section{Scheme 1}

The acetylenes 13 and 14 were prepared using via [2,3]-sigmatropic rearrangement of allyl propargyl ether 16 (Scheme 2). Propargyl alcohol was converted to its $C$-trimethylsilyl derivative $15^{8}$ via formation of the dianion using two equivalents of butyllithium followed by quenching with trimethylsilyl chloride. Subsequent allylation using conditions reported in the literature ${ }^{9}$ (ethylmagnesium bromide and HMPA) afforded allyl propargyl ether 16. Unfortunately attempts to carry out this reaction using alternative reagents such as sodium hydride / allyl bromide, butyllithium / allyl bromide, ethyl bromide / allyl bromide were unsuccessful hence the use of the highly toxic agent HMPA could not be avoided. Treatment of allyl propargyl ether 16 with butyllithium at $-78{ }^{\circ} \mathrm{C}$ for $10 \mathrm{~min}$. effected smooth [2,3]-sigmatropic rearrangement to alcohol 17. ${ }^{10}$ Subsequent $O$-silylation with tert-butyldimethylsilyl chloride or tert-butyldiphenylsilyl chloride afforded silyl ethers 18 and 19 respectively, which then underwent $C$-desilylation upon treatment with sodium methoxide to afford acetylenes 13 and 14.

Aldehyde 12 was prepared (Scheme 3) from 1,4-pentanediol by monoacetylation of the primary alcohol using 3-acetyltetrahydrothiazole-2-thione ${ }^{11,12}$ to obtain acetate $\mathbf{2 0}^{13}$ followed by protection of the secondary alcohol as a tert-butyldimethyl silyl ether $21 .{ }^{14}$ Selective removal of the acetate using potassium carbonate in methanol then afforded primary alcohol $22^{14}$ which underwent oxidation to the required aldehyde $12^{15}$ using Dess-Martin periodinane. ${ }^{16}$ 


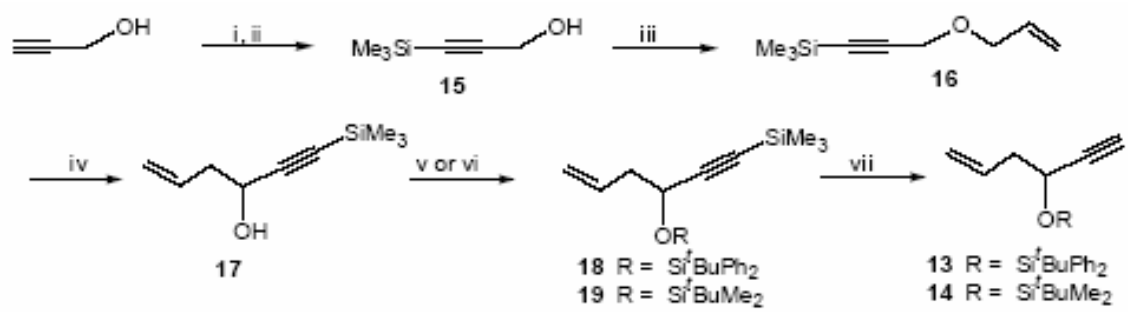

Reagents and Conditions: (i) ${ }^{n} \mathrm{BuLi}, \mathrm{THF},-78{ }^{\circ} \mathrm{C}$ to room temp. (ii) $1 \mathrm{M}, \mathrm{HCl}, 0.5 \mathrm{~h}, 70 \%$ (iii) 1.2 M EtMgBr, HMPA (4.0 equiv.), THF, $0{ }^{\circ} \mathrm{C}, 5$ min. Then allyl bromide, $\Delta, 4$ h., $67 \%$; (iv) ${ }^{n} \mathrm{BuLi}$, THF, $-78{ }^{\circ} \mathrm{C}, 10$ min., $97 \%$; (v) ${ }^{t} \mathrm{BuPh}_{2} \mathrm{SiCl}$, DMAP, imidazole, $\mathrm{CH}_{2} \mathrm{Cl}_{2}$ room temp., 4 h., $98 \%$. (vi) ${ }^{t} \mathrm{BuMe} 2 \mathrm{SiCl}$, DMAP, imidazole, $\mathrm{CH}_{2} \mathrm{Cl}_{2}$, room temp., 4h., $98 \%$. (vii) $\mathrm{NaOMe}, \mathrm{MeOH}$, 1h., 13, $88 \%$; 14, 96\%.

Scheme 2

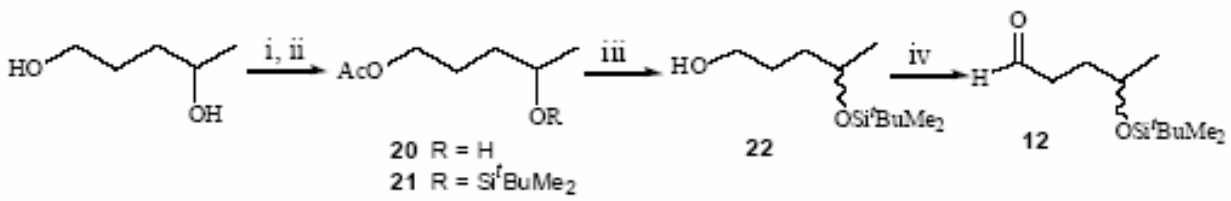

Reagents and Conditions: (i) 3-acetyltetrahydrothiazole-2-thione, NaH, THF, 2h, room temp., $82 \%$. (ii) ${ }^{t} \mathrm{BuMe}_{2} \mathrm{SiCl}$, DMAP, imidazole, DMF, room temp., 4 h., 95\%. (iii) $\mathrm{K}_{2} \mathrm{CO}_{3}, \mathrm{MeOH}$, room temp., 18h., 92\%. (iv) Dess-Martin periodinane, $\mathrm{CH}_{2} \mathrm{Cl}_{2}$, py, $1 \mathrm{~h}, 94 \%$.

\section{Scheme 3}

With quantities of aldehyde 12 and acetylenes 13 and 14 in hand, our attention next focused on their union via formation of the lithium acetylide (Scheme 4). Treatment of acetylene 13 in which the hydroxyl group is protected as robust tert-butyldiphenylsilyl ether with butyllithium in THF at $-78{ }^{\circ} \mathrm{C}$ for $1 \mathrm{~h}$ Followed by treatment with aldehyde 12 failed to generate the desired alcohol 23. In all cases unreacted acetylene 13 was recovered from the reaction.

In order to test whether butyllithium was in fact removing the acetylene proton prior to the addition of aldehyde 12, a series of quenches with deuterium oxide were performed. As a result of these studies, it was established that both butyllithium and tert-butyllithium were insufficiently basic to remove the acetylenic proton. Use of Schlosser's base ${ }^{17}$ (a mixture of butyllithium and potassium tert-butoxide) effected deprotonation under these conditions and resulted in $100 \%$ incorporation of deuterium. Disappointingly, application of these conditions to the addition of the acetylide of acetylene $\mathbf{1 3}$ to aldehyde $\mathbf{1 2}$ only afforded the desired alcohol $\mathbf{2 3}^{\#}$ in $28 \%$ yield.

Attempts to optimise the use of Schlosser's base to effect this reaction proved uneventful. The principal side reactions observed were desilylation of acetylene $\mathbf{1 3}$ and aldehyde 12. Our attention then turned to the use of butyllithium with TMEDA as a cosolvent. The efficacy of the butyllithium / TMEDA system was first demonstrated by a deuterium quench and ultimately the coupling of acetylene $\mathbf{1 3}$ with aldehyde 12 to afford alcohol 23 proceeded in $85 \%$ yield. 
Use of a tert-butyldiphenylsilyl ether to protect the hydroxyl group in acetylene $\mathbf{1 3}$ proved problematic in the subsequent deprotection step (vide infra). Thus, a parallel study was also undertaken using acetylene $\mathbf{1 4}$ which bears a more labile tert-butyldimethylsilyl ether.

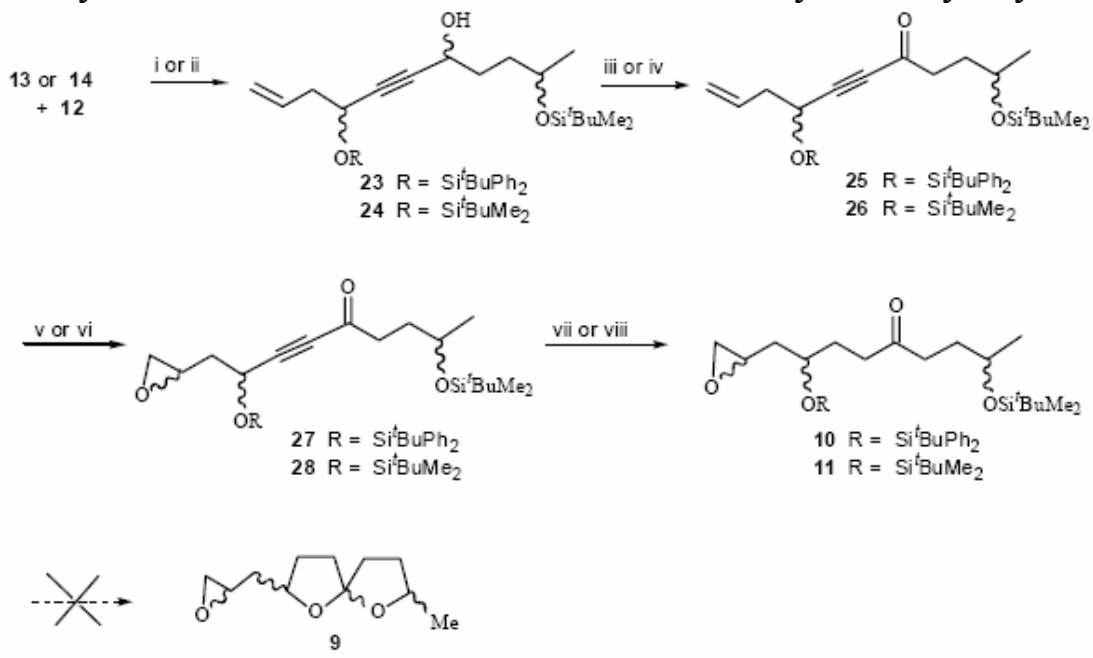

Reagents and Conditions: (i) $13,{ }^{n} \mathrm{BuLi}$, TMEDA ( 2.5 equiv.), THF, $-78^{\circ} \mathrm{C}, 1 \mathrm{~h}$., then $15,0.5 \mathrm{~h}$., $85 \%$. (ii) 14, ${ }^{n} \mathrm{BuLi}$, TMEDA (2.5 equiv.), THF, $-78^{\circ} \mathrm{C}, 50 \mathrm{~min}$., then add to (15), $0.5 \mathrm{~h}$., $52 \%$. (iii) 23, Dess-Martin periodinane, $\mathrm{CH}_{2} \mathrm{Cl}_{2}$, room temp., $83 \%$. (iv) 24, TPAP, $\mathrm{NMO}, \mathrm{CH}_{2} \mathrm{Cl}_{2}$, room temp., 0.5h., $98 \%$. (v) 25, $m$-CPBA, $\mathrm{NaOAc}, \mathrm{CH}_{2} \mathrm{Cl}_{2}$, room temp., 5 days, $79 \%$. (vi) 26, $m$ CPBA, $\mathrm{NaOAc}, \mathrm{CH}_{2} \mathrm{Cl}_{2}$, room temp., 5 days, $75 \%$. (vii) 27, $10 \% \mathrm{Pd} / \mathrm{C}, \mathrm{H}_{2}$, EtOAc, $\mathrm{NaHCO}_{3}$, 2h., 98\%; (viii) 28, 10\% Pd/C, $\mathrm{H}_{2}$, EtOAc, $\mathrm{NaHCO}_{3}$, 2h., 74\%.

\section{Scheme 4}

In this latter case the addition of the acetylide of acetylene 14 to aldehyde 12 was only achieved by adding the acetylide to a solution of the aldehyde (reverse addition) affording alcohol 24 in a modest $52 \%$ yield.

Alcohols 23 and 24 underwent smooth oxidation in good yield to ketones 25 and 26 using Dess-Martin periodinane or tetrapropylammonium perruthenate and $N$-methylmorpholine- $N$ oxide respectively. Subsequent selective epoxidation of the terminal alkenes 25 and 26 using meta-chloroperbenzoic acid buffered with sodium acetate effected smooth conversion to epoxy ynones 10 and 11 respectively. Finally removal of the triple bond by hydrogenation over palladium on charcoal afforded the key saturated keto epoxides $\mathbf{1 0}$ and $\mathbf{1 1}$ which were precursors to the desired 5,5-spiroacetal 9.

At this stage it was envisaged that deprotection of both the silyl ethers in keto epoxides $\mathbf{1 0}$ and 11 would liberate a diol which would immediately undergo cyclization to the desired spiroacetal 9. Unfortunately initial attempts to effect this transformation using silyl ether $\mathbf{1 0}$ which bears a robust tert-butyldiphenylsilyl ether at $\mathrm{C}-8$, were unproductive, hence the analogous bis-silyl ether $\mathbf{1 1}$ was prepared which bore a more labile tert-butyldimethylsilyl ether at C-8. Unfortunately attempts to deprotect bis-silyl ether $\mathbf{1 1}$ using a variety of conditions such as tetrabutylammonium fluoride, $\mathrm{HF} /$ pyridine and pyridinium $p$-toluenesulfonate in dichloromethane or methanol afforded complex mixtures for which the ${ }^{1} \mathrm{H}$ n.m.r. spectra of the 
crude product mixture clearly indicated that the epoxide had undergone reaction.

A solution to this problem was found by forming the two five membered rings of 5,5spiroacetal 9 sequentially (Scheme 5). Treatment of bis-silyl ether $\mathbf{2 6}$ with a catalytic quantity of camphorsulfonic acid in methanol afforded methyl acetal 29 in 97\% yield which then underwent selective epoxidation of the terminal alkene using meta-chloroperbenzoic acid buffered with sodium acetate affording epoxide $\mathbf{3 0}$ in $89 \%$ yield. The long reaction times required to effect this epoxidation and the epoxidation of alkenes $\mathbf{2 5}$ and $\mathbf{2 6}$ above, was somewhat surprising, nevertheless epoxidation of alkene $\mathbf{2 9}$ in the presence of the alkyne did proceed selectively. Finally hydrogenation of alkyne over palladium on charcoal in the presence of sodium bicarbonate as buffer afforded the key 5,5-spiroacetal 9 in 63\% yield. The modest yield for this step was attributed to the volatility of this compound.

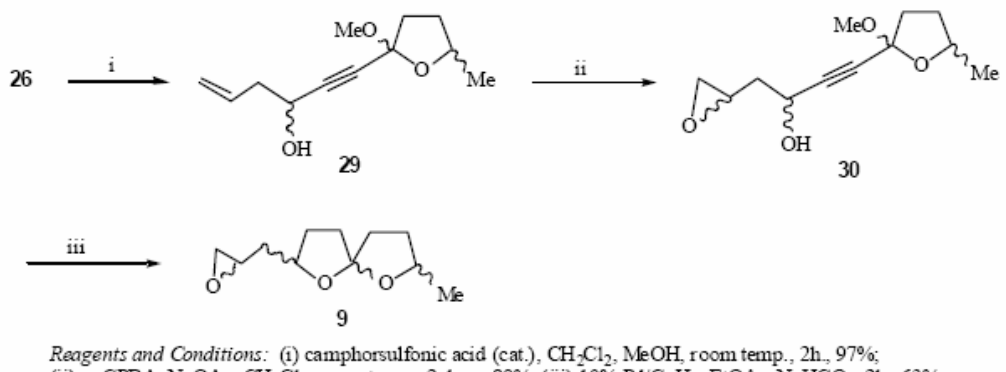

(ii) $m$-CPBA, NaOAc, $\mathrm{CH}_{2} \mathrm{Cl}_{2}$, room temp., 2 days, $89 \%$; (iii) $10 \% \mathrm{Pd} / \mathrm{C}, \mathrm{H}_{2}, \mathrm{EtOAc}, \mathrm{NaHCO}_{3}, 2 \mathrm{~h}, 63 \%$.

\#In all of the reactions described a mixture of stereoisomers was obtained which were not separated.

Reagents and Conditions: (i) camphorsulfonic acid (cat.), $\mathrm{CH}_{2} \mathrm{Cl}_{2}, \mathrm{MeOH}$, room temp., 2h., $97 \%$. (ii) $m$-CPBA, $\mathrm{NaOAc}, \mathrm{CH}_{2} \mathrm{Cl}_{2}$, room temp., 2 days, $89 \%$. (iii) $10 \% \mathrm{Pd} / \mathrm{C}, \mathrm{H}_{2}, \mathrm{EtOAc}, \mathrm{NaHCO}_{3}$, $2 \mathrm{~h} ., 63 \%$.

\section{Scheme 5}

Having successfully prepared spiroacetal 9, albeit as a mixture of all possible stereoisomers, it was next decided to extend the synthetic methodology developed herein to execute a stereocontrolled synthesis of spiroacetal 9. In order to prepare anti-Helicobacter pylori agents CJ-12,954 1 and CJ-13,014 2 with the required 2S, 7S configuration of the 5,5-spiroacetal ring system, a synthesis of spiroacetals $9 \mathbf{a}$ or $\mathbf{9 b}$ which have the correct $2 S, 7 R$ stereochemistry must be achieved. The stereochemistry of the spirocentre or the epoxide does not need to be controlled as the stereocentre in the epoxide is removed in a subsequent step and it was anticipated that two stereoisomers of the 5,5-spiroacetal, which differ only in the configuration of the spirocentre, would always be formed in the final spirocyclization step.

Applying the synthetic methodology reported herein to the synthesis of spiroacetal 9 with the correct $2 S, 7 R$ stereochemistry requires the synthesis of $(S)$-acetylene $\mathbf{1 4}$ and (S)-aldehyde 12. $(S)$-Aldehyde 12 is available from $(S)$-1,4-pentanediol which in turn is readily prepared from ethyl 4-oxopentanoate by enantioselective reduction of the ketone with bakers' yeast ${ }^{18}$ followed by reduction of the ester using lithium aluminium hydride.

It was envisaged that acetylene $\mathbf{1 4}$ would be available in enantioenriched form by extending the key [2,3]-sigmatropic rearrangement of allyl propargyl ether $\mathbf{1 6}$ in an asymmetric sense. ${ }^{19}$ 
Towards this end, allyl propargyl ether was subjected to [2,3]-sigmatropic rearrangement using butyllithium in the presence of the chiral bases (-)-sparteine, ${ }^{20}(1 R, 2 S)$-(-)-norephedrine and $[R$ $\left.\left(R^{*}, R^{*}\right)\right]$ - $(+)$-bis $(\alpha$-methylbenzylamine). Disappointingly alcohol 17 was only obtained as a racemic mixture in all cases.

The successful completion of the synthesis of spiroacetal epoxide 9, albeit as a mixture of stereoisomers, constitutes a synthesis of the spiroacetal moiety of CJ-12, 9541 and CJ-13, 0142. It now remains to append the phthalide fragment 8 to this spiroacetal fragment. The inability to effect the key [2,3]-sigmatropic rearrangement of allyl propargyl ether $\mathbf{1 6}$ to alcohol $\mathbf{1 7}$ in an asymmetric fashion has necessitated that future work also be directed towards a synthesis of this 5,5-spiroacetal 9 using methodology that enables control of the stereochemistry at C-2 and C-7 of the spiroacetal ring system.

\section{Experimental Section}

General Procedures. Melting points were determined using a Kofler hot-stage apparatus and are uncorrected. Infrared spectra were recorded with a Perkin-Elmer 1600 series Fourier-transform infrared spectrometer as thin films between sodium chloride plates. ${ }^{1} \mathrm{H}$ and ${ }^{13} \mathrm{C}$ n.m.r spectra were obtained using either at Bruker AC200 spectrometer or a Bruker DRX-400 spectrometer. Both ${ }^{1} \mathrm{H}$ and ${ }^{13} \mathrm{C}$ n.m.r spectra were interpreted with the aid COSY, HETCOR and DEPT 135 experiments and are reported downfield from tetramethylsilane as standard. High-resolution mass spectra were recorded using a VG7070 spectrometer operating with an ionisation potential of $70 \mathrm{eV}$ at a nominal resolution of 5000 or 10000 as appropriate. Major fragments are given as percentages of the base peak and are assigned where possible. Tetrahydrofuran and diethyl ether were dried using sodium/benzophenone and distilled prior to use. Flash chromatography was performed using Merck Kieselgel 60 or Riedel-de-Haen Kieselgel S silica gel (both 230-400 mesh) with the indicated solvents. Compounds were visualized under ultraviolet light or by staining with iodine or vanillin in methanolic sulfuric acid.

3-(Trimethylsilyl)prop-2-yn-1-ol (15). Butyllithium (21.4 mL, $10 \mathrm{M}$ in hexanes, $214 \mathrm{mmol})$ was added to a solution of propargyl alcohol $(5.0 \mathrm{~g}, 89.0 \mathrm{mmol})$ in dry THF $(190 \mathrm{ml})$ cooled to $78{ }^{\circ} \mathrm{C}$ under nitrogen. After $0.5 \mathrm{~h}$ trimethylsilyl chloride $(28.0 \mathrm{~mL}, 223.3 \mathrm{mmol})$ was added and the resultant mixture was warmed to room temperature and stirred for $1 \mathrm{~h}$. Freshly prepared $1 \mathrm{M}$ $\mathrm{HCl}(50 \mathrm{~mL})$ was added, the mixture stirred vigorously for $0.5 \mathrm{~h}$. and extracted with diethyl ether $(50 \mathrm{~mL})$. The combined organic extracts were washed with brine, dried over $\mathrm{MgSO}_{4}$ and evaporated in vacuo. Distillation of the residue under reduced pressure afforded the title compound 15 (8.0 g, 70\%) as a colourless mobile liquid, bp 100-110 ${ }^{\circ} \mathrm{C} / 20 \mathrm{mmHg}$ (lit. ${ }^{8} \mathrm{bp}$ $\left.120{ }^{\circ} \mathrm{C} / 20 \mathrm{mmHg}\right)$.

1-(Allyloxy)-3-(trimethylsilyl)prop-2-yne (16). A stock solution of ethylmagnesium bromide was prepared as follows. To a stirred suspension of magnesium powder $(0.30 \mathrm{~g}, 12.5 \mathrm{mmol})$ in THF $(10 \mathrm{~mL})$ at $25^{\circ} \mathrm{C}$ was added bromoethane $(1.03 \mathrm{~mL}, 13.9 \mathrm{mmol})$. The mixture was heated under reflux until initiation occurred then stirred for $1 \mathrm{~h}$. at room temperature to afford a $1.2 \mathrm{M}$ solution of ethylmagnesium bromide. To a stirred solution of 3-(trimethylsilyl)prop-2-yn-1-ol, 15 $(0.25 \mathrm{~g}, 1.95 \mathrm{mmol})$ in THF $(10 \mathrm{~mL})$ and HMPA $(1.36 \mathrm{~mL}, 7.8 \mathrm{mmol})$ at $0{ }^{\circ} \mathrm{C}$ under nitrogen 
was added ethylmagnesium bromide $(1.75 \mathrm{~mL}, 1.2 \mathrm{M}, 2.15 \mathrm{mmol})$. The mixture was stirred for 5 min, treated with 3-bromo-1-propene $(0.35 \mathrm{~g}, 2.9 \mathrm{mmol})$ then heated under reflux for $4 \mathrm{~h}$. The reaction mixture was cooled to room temperature, quenched by the addition water $(3 \mathrm{~mL})$ and 1 $\mathrm{M} \mathrm{HCl}(5 \mathrm{~mL})$ then extracted with diethyl ether $(25 \mathrm{~mL})$. The organic phase was further washed with water $(2 \times 10 \mathrm{~mL})$ and brine $(10 \mathrm{~mL})$ then dried over $\mathrm{MgSO}_{4}$. Evaporation of the solvent in vacuo followed by flash chromatography of the residue using $2 \%$ diethyl ether - hexane as eluent afforded the title compound $16(0.22 \mathrm{~g}, 67 \%)$ as a colourless oil for which the ${ }_{1} \mathrm{H}$ NMR were in agreement with the literature. ${ }^{9}$

1-Trimethylsilylhex-5-en-1-yn-3-ol (17). Butyllithium (2.5 mL, 1.6 M in hexanes, $4.0 \mathrm{mmol})$ was added to a stirred solution of 1-allyloxy-3-trimethylsilylprop-2-yne 16 (1.0 g, $4.0 \mathrm{mmol})$ in THF $(40 \mathrm{~mL})$ at $-78{ }^{\circ} \mathrm{C}$ under nitrogen. The reaction was stirred for $20 \mathrm{~min}$, warmed to $-30{ }^{\circ} \mathrm{C}$ then quenched by the addition of $10 \%$ ammonium chloride $(5 \mathrm{~mL})$. The mixture was further warmed to room temperature, diluted with diethyl ether $(30 \mathrm{~mL})$ then washed successively with water $(3 \times 10 \mathrm{~mL})$ and brine $(10 \mathrm{~mL})$. The organic extract was dried over $\mathrm{MgSO}_{4}$ and evaporated in vacuo to afford the title compound $(0.97 \mathrm{~g}, 97 \%)$ as light yellow oil for which the ${ }^{1} \mathrm{H}$ NMR. data were in agreement with the literature. ${ }^{10}$

1-(Trimethylsilyl)-3-(tert-butyldiphenylsilyloxy)hex-5-en-1-yne (18). To a stirred solution of 1-(trimethylsilyl)hex-5-en-1-yn-3-ol 17 (250 mg, $1.48 \mathrm{mmol})$, imidazole (120 mg, $1.78 \mathrm{mmol})$ and 4-(dimethylaminopyridine) $(18 \mathrm{mg}, 0.15 \mathrm{mmol})$ in dichloromethane $(10 \mathrm{~mL})$ at room temperature was added dropwise tert-butyldiphenylsilyl chloride $(0.49 \mathrm{~g}, 1.78 \mathrm{mmol})$. After $1 \mathrm{~h}$, the reaction was quenched by the addition $\mathrm{NaHCO}_{3}(2 \mathrm{~mL})$ and water $(10 \mathrm{~mL})$ and the resultant mixture extracted with dichloromethane $(3 \times 10 \mathrm{ml})$. The organic extracts were dried over $\mathrm{MgSO}_{4}$ and then evaporated in vacuo to afford the title compound $\mathbf{1 8}^{11}$ as a light yellow oil (580 $\mathrm{mg}, 98 \%$ ) that was immediately used in the next step without further purification.

1-(Trimethylsilyl)-3-(tert-butyldimethylsilyloxy)hex-5-en-1-yne (19). To a solution of alcohol $17(6.64 \mathrm{~g}, 0.039 \mathrm{~mol})$, imidazole $(2.95 \mathrm{~g}, 0.043 \mathrm{~mol})$ and 4-dimethylaminopyridine $(0.5 \mathrm{~g}$, $0.004 \mathrm{mmol})$ in dichloromethane $(80 \mathrm{~mL})$ at room temperature was added tert-butyldimethylsilyl chloride $(6.23 \mathrm{~g}, 0.041 \mathrm{~mol})$. After $1 \mathrm{~h}$, the reaction was quenched by the addition of $10 \%$ $\mathrm{NaHCO}_{3}$ solution $(20 \mathrm{~mL})$ and water $(50 \mathrm{~mL})$ and the resultant mixture extracted with dichloromethane $(3 \times 50 \mathrm{~mL})$. The organic extracts were washed with brine $(10 \mathrm{~mL})$, dried over $\mathrm{MgSO}_{4}$ then evaporated in vacuo to afford the title compound 19 as light yellow oil (10.9 g, $98 \%$ ) that was immediately used in the next step without further purification. ${ }^{21}$

3-(tert-Butyldiphenylsilyloxy)hex-5-en-1-yne (13). To a stirred solution of acetylene 18 $(70 \mathrm{mg}, 0.17 \mathrm{mmol})$ in methanol $(1 \mathrm{~mL})$ at room temperature was added a freshly prepared solution of sodium methoxide (12 $\mathrm{mg}$ sodium in $5 \mathrm{ml}$ methanol). The reaction mixture was then heated at $45^{\circ} \mathrm{C}$ for $20 \mathrm{~min}$. The mixture was cooled to room temperature then evaporated in vacuo to a volume of $\sim 1 \mathrm{~mL}$. The residue was diluted with water $(5 \mathrm{ml})$, extracted with diethyl ether $(3 \times 10 \mathrm{~mL})$, washed with brine $(3 \mathrm{ml})$, dried over $\mathrm{MgSO}_{4}$ then evaporated in vacuo. The title compound $\mathbf{1 3}^{22}$ (50 mg, 88\%) was afforded as colorless oil. (Found: $\mathrm{M}^{+\bullet}, 334.1744$. $\mathrm{C}_{22} \mathrm{H}_{26} \mathrm{OSi}$ requires $\mathrm{M}^{+\bullet}$, 334.1753). IR: $v_{\max } 3000,1728,1473,1112,1083,701 \mathrm{~cm}^{-1}$. ${ }^{1} \mathrm{H}$ NMR: $\delta\left(400 \mathrm{MHz}, \mathrm{CDCl}_{3}\right)$ 1.08, s, 9H, C(CH$)_{3} ; 2.33, \mathrm{~d}, J_{1,3} 2.1 \mathrm{~Hz}, 1 \mathrm{H}, \mathrm{H} 1 ; 2.31-2.39, \mathrm{~m}, 1 \mathrm{H}, \mathrm{H} 4 \alpha$; 2.44 , ddt, $J_{4 \beta, 4 \alpha} 12.7, J_{4 \beta, 3} 7.0$, and $J_{4 \beta, 6} 1.3 \mathrm{~Hz}, 1 \mathrm{H}, \mathrm{H} 4 \beta ; 4.37$, ddd, $J_{3,4 \alpha} 5.5, J_{3,4 \beta} 7.0$, and $J_{3,1}$ $2.1 \mathrm{~Hz}, 1 \mathrm{H}, \mathrm{H} 3 ;$ 5.03-5.08, m, 2H, H6; 5.8-5.87, m, 1H, H5; 7.35-7.7, m, 10H, 2 x Ar; ${ }^{13} \mathrm{C}$ NMR 
$\delta\left(100 \mathrm{MHz}, \mathrm{CDCl}_{3}\right)$ 19.3, $\mathrm{C}\left(\mathrm{CH}_{3}\right)_{3} ; 26.9, \mathrm{C}\left(\mathrm{CH}_{3}\right)_{3} ; 42.7, \mathrm{C} 4 ; 63.4, \mathrm{C} 3 ; 72.9, \mathrm{C} 1 ; 84.4, \mathrm{C} 2 ;$ 117.9, C6; 127.4, 127.6, 129.7, 129.8, 135.9 and 136.0 (Ar), 133.3, C5; MS: m/z 334 (M, 6\%), 277 (100), 207 (60), 199 (45).

3-(tert-Butyldimethylsilyloxy)hex-5-en-1-yne (14). To a stirred solution of acetylene 19 $(11.0 \mathrm{~g}, 0.039 \mathrm{~mol})$ in methanol $(20 \mathrm{~mL})$ at room temperature was added a freshly prepared solution of sodium methoxide in methanol $(2.7 \mathrm{~g}$ sodium in $112 \mathrm{~mL}$ methanol). The reaction mixture was then heated to $45{ }^{\circ} \mathrm{C}$ for $20 \mathrm{~min}$. The resultant mixture was cooled to room temperature then evaporated in vacuo to a volume of $\sim 5 \mathrm{~mL}$. The residue was diluted with water $(5 \mathrm{~mL})$, extracted with dichloromethane $(4 \times 10 \mathrm{~mL})$, dried over $\mathrm{MgSO}_{4}$, then evaporated in vacuo. The title compound $\mathbf{1 4}$ was afforded as a colorless oil $(7.86 \mathrm{~g}, 96 \%)$ for which the ${ }^{1} \mathrm{H}$ NMR data was in good agreement with the literature. ${ }^{23,24}$

3-Acetyltetrahydrothiazole-2-thione. To a vigorously stirred solution of mercaptothiazoline (3.0 g, $26 \mathrm{mmol})$ and triethylamine $(3.26 \mathrm{~g}, 33 \mathrm{mmol})$ in THF $(60 \mathrm{ml})$ at room temperature was added acetyl chloride $(2.28 \mathrm{ml}, 33 \mathrm{mmol})$. An intense yellow color was immediately observed. After $18 \mathrm{~h}$ the reaction was diluted with water $(30 \mathrm{ml})$ and the resultant mixture extracted with dichloromethane $(3 \times 40 \mathrm{~mL})$. The combined extracts were washed with brine $(30 \mathrm{ml})$, dried over $\mathrm{MgSO}_{4}$ and evaporated in vacuo. Flash chromatography of the residue using $50 \%$ diethyl ether hexane as eluent afforded the title compound $(4.1 \mathrm{~g}, 98 \%)$ as a luminous yellow oil. ${ }^{11,12}$

4-Hydroxy-pent-1-yl acetate (20). To a stirred solution of 1,4-pentanediol (1 g, $9.6 \mathrm{mmol})$ and 3-acetyltetrahydrothiazole-2-thione $(1.6 \mathrm{~g}, 10.1 \mathrm{mmol})$ in THF $(60 \mathrm{~mL})$ at room temperature was added portionwise sodium hydride $(240 \mathrm{mg}, 10.1 \mathrm{mmol})$. After $2 \mathrm{~h}$ the reaction was quenched by the addition of $10 \%$ ammonium chloride $(30 \mathrm{ml})$ and the resultant mixture extracted with dichloromethane $(2 \times 50 \mathrm{ml})$. The combined extracts were washed with brine $(30 \mathrm{ml})$, dried over $\mathrm{MgSO}_{4}$ and evaporated in vacuum to afford the title compound 20 (1.15 g, 82\%) as a pale yellow solid. $^{13}$

4-(tert-Butyldimethylsilyloxy)pent-1-yl acetate (21). To a stirred solution of alcohol 20 (1.15 g, $7.9 \mathrm{mmol})$, imidazole $(0.72 \mathrm{~g}, 10.6 \mathrm{mmol})$ and 4-dimethylaminopyridine (117 $\mathrm{mg}, 0.96 \mathrm{mmol})$ in DMF $(20 \mathrm{~mL})$ at room temperature was added tert-butyldimethylsilyl chloride (1.44 $\mathrm{g}$, $9.6 \mathrm{mmol}$ ) in small portions. After $4 \mathrm{~h}$ the reaction was quenched by the addition of saturated ammonium chloride $(15 \mathrm{~mL})$ and water $(10 \mathrm{~mL})$ then the mixture was diluted with diethyl ether $(30 \mathrm{~mL})$. The organic phase was separated, washed with water $(2 \times 10 \mathrm{~mL})$, brine $(5 \mathrm{~mL})$ then dried over $\mathrm{MgSO}_{4}$. Evaporation of the organic extract in vacuo followed by flash chromatography of the residue using $20 \%$ diethyl ether - hexane as eluent afforded the title compound $2 \mathbf{1}^{14}(1.93 \mathrm{~g}, 95 \%)$ as a light yellow oil for which the ${ }^{1} \mathrm{H}$ NMR data was in good agreement with the literature. $^{14}$

4-(tert-Butyldimethylsilyloxy)pentan-1-ol (22). To a stirred solution of acetate 21 (1.93 g, $7.4 \mathrm{mmol})$ in methanol $(35 \mathrm{~mL})$ at room temperature was added $\mathrm{K}_{2} \mathrm{CO}_{3}(2.0 \mathrm{~g}, 14.6 \mathrm{mmol})$ in small portions. The mixture was stirred for $18 \mathrm{~h}$, filtered through a short pad of Celite ${ }^{\mathrm{TM}}$ then evaporated in vacuo. Flash chromatography of the residue using $40 \%$ diethyl ether - hexane as eluent afforded the title compound $22(1.5 \mathrm{~g}, 92 \%)$ as a colorless oil for which the ${ }^{1} \mathrm{H}$ n.m.r. data was in good agreement with the literature. ${ }^{14}$

4-(tert-Butyldimethylsilyloxy)pentanal (12). Dess-Martin periodinane ${ }^{16}$ (2.1 g, $\left.4.97 \mathrm{mmol}\right)$ was added portionwise to a mixture of alcohol $22(540 \mathrm{mg}, 2.48 \mathrm{mmol})$ and pyridine $(0.2 \mathrm{~mL})$ in 
dichloromethane $(35 \mathrm{~mL})$ at room temperature. After $1 \mathrm{~h}$ the suspension was filtered through a short pad of Celite ${ }^{\mathrm{TM}}(2 \mathrm{~cm} \times 0.4 \mathrm{~cm})$ and the filtrate diluted with $\mathrm{NaOH}(1.3 \mathrm{M}, 10 \mathrm{ml})$. The resultant mixture was extracted with dichloromethane $(3 \times 10 \mathrm{~mL})$ and the organic extracts dried over $\mathrm{MgSO}_{4}$ then concentrated at reduced pressure. Flash chromatography of the residue using 5\% diethyl ether - hexane as eluent afforded the title compound 12 (500 mg, 94\%) as a mobile colorless liquid for which the ${ }^{1} \mathrm{H}$ NMR data was in good agreement with the literature. ${ }^{15}$

2-(tert-Butyldimethylsilyloxy)-8-(tert-butyldiphenylsilyloxy)undec-10-en-6-yn-5-ol

(23). Butyllithium $(0.20 \mathrm{~mL}, 1.6 \mathrm{M}$ in hexane, $0.32 \mathrm{mmol})$ was added to a mixture of alkyne 13 (90 $\mathrm{mg}, 0.27 \mathrm{mmol})$ and tetramethylethylenediame $(94 \mathrm{mg}, 0.8 \mathrm{mmol})$ in THF $(2.5 \mathrm{~mL})$ at $78{ }^{\circ} \mathrm{C}$ under nitrogen. The mixture was stirred for $1 \mathrm{~h}$ then treated with a solution of aldehyde 12 (70 $\mathrm{mg}, 0.32 \mathrm{mmol})$ in THF $(0.5 \mathrm{~mL})$. Stirring was continued for $30 \mathrm{~min}$ then the reaction was quenched by the addition of $10 \% \mathrm{NaHCO}_{3}(1 \mathrm{~mL})$ and water $(3 \mathrm{~mL})$. The resultant mixture was warmed to room temperature and extracted with diethyl ether $(3 \times 10 \mathrm{ml})$. The organic extracts were washed successively with brine $(3 \mathrm{~mL})$, dried over $\mathrm{MgSO}_{4}$ then evaporated in vacuo. Flash chromatography of the residue using $15 \%$ diethyl ether - hexane as eluent afforded the title compound 23 (127 mg, 85\%) as colorless oil. (Found: $\mathrm{M}^{+\bullet}, 551.3375 . \mathrm{C}_{33} \mathrm{H}_{50} \mathrm{Si}_{2} \mathrm{O}_{3}$ requires $\mathrm{M}^{+\bullet}$, 551.3377). $v_{\max } 3429,3000-2800,1472,1428,1361,1255,1112,835 \mathrm{~cm}^{-1} .{ }^{1} \mathrm{H}$ NMR: $\delta$ $\left(400 \mathrm{MHz}, \mathrm{CDCl}_{3}\right)$ 0.04, 2 x s, 6H, Si $\left.\left(\mathrm{CH}_{3}\right)_{2}\right), 0.87, \mathrm{~s}, 9 \mathrm{H}, \mathrm{C}\left(\mathrm{CH}_{3}\right)_{3} ; 1.06, \mathrm{~s}, 9 \mathrm{H}, \mathrm{C}\left(\mathrm{CH}_{3}\right)_{3} ; 1.10$, d, J 6.1 Hz, 3H, H1; 1.40-1.62, m, 4H, H3 and H4; 2.39-2.46, m, 2H, H9; 3.75-3.83, m, 1H, H2; 4.17-4.19, m, 1H, H5; 4.41-4.47, m, 1H, H8; 5.00-5.10, m, 2H, H11; 5.78-5.92, m, 1H, H10; 7.26-7.70, m, 10H, 2 x Ph. ${ }^{13} \mathrm{C}$ NMR: $\delta\left(100 \mathrm{MHz}, \mathrm{CDCl}_{3}\right)-4.75,-4.44, \mathrm{SiCH}_{3} ; 18.1,19.2$, $\mathrm{C}\left(\mathrm{CH}_{3}\right)_{3} ; 23.3,23.5,23.6, \mathrm{C1} ; 25.8, \mathrm{C}\left(\mathrm{CH}_{3}\right)_{3} ; 26.9, \mathrm{C}\left(\mathrm{CH}_{3}\right)_{3} ; 33.1,33.2,33.5,33.6, \mathrm{C} 3 ; 34.5$, 34.9, C4; 42.9, C9; 62.1, 62.4, C5; 63.5, C8; 68.1, 68.2, C2; 85.5, 85.7, C7; 86.1, 86.4, C6; 117.8, C11; 133.5, 133.7, 134.1, C10; 127.3, 127.6, 129.6, 129.7, 135.9, 136.1 (Ar). MS: m/z (CI) $551\left(\mathrm{MH}^{+}, 0.5 \%\right), 361$ (30), 199 (90), 159 (50), 75 (100).

2,8-Bis(tert-butyldimethylsilyloxy)undec-10-en-6-yn-5-ol (24). Butyllithium (2 mL, 1.6 M in hexane, $3.24 \mathrm{mmol}$ ) was added to a mixture of acetylene 14 (570 $\mathrm{mg}, 2.7 \mathrm{mmol})$, tetramethylethylenediamine $(1.21 \mathrm{~mL}, 8.1 \mathrm{mmol})$ in THF $(10 \mathrm{~mL})$ at $-78{ }^{0} \mathrm{C}$. The mixture was stirred for $50 \mathrm{~min}$ then transferred via cannula to a solution of aldehyde 12 (700 $\mathrm{mg}, 3.24 \mathrm{mmol}$ ) in THF $(10 \mathrm{~mL})$. Stirring was continued for a further $30 \mathrm{~min}$ and the reaction quenched by the addition of $10 \% \mathrm{NaHCO}_{3}(5 \mathrm{~mL})$ and water $(10 \mathrm{~mL})$. The mixture was warmed to room temperature and extracted with diethyl ether $(3 \times 15 \mathrm{~mL})$. The organic extracts were washed with brine $(10 \mathrm{~mL})$, dried over $\mathrm{MgSO}_{4}$ and evaporated in vacuo. Flash chromatography of the residue using 10\% diethyl ether - hexane as eluent afforded the title compound 24 (600 mg, 52\%) as colorless oil. (Found: $\mathrm{MH}^{+\bullet}, 427.3062 . \mathrm{C}_{23} \mathrm{H}_{47} \mathrm{O}_{3} \mathrm{Si}_{2}$ requires $\mathrm{MH}^{+\bullet}, 427.3064$ ). $v_{\max } 2929,1472$, 1255, 1089, $836 \mathrm{~cm}^{-1} .{ }^{1} \mathrm{H}$ NMR: $\delta\left(400 \mathrm{MHz} \mathrm{CDCl}_{3}\right)$ 0.04, 0.05, 0.09, 0.10, each s, $12 \mathrm{H}, \mathrm{SiCH}_{3}$; $0.88, \mathrm{~s}, 9 \mathrm{H}, \mathrm{C}\left(\mathrm{CH}_{3}\right)_{3} ; 0.89$, s, 9H, $\mathrm{C}\left(\mathrm{CH}_{3}\right)_{3} ; 1.13, \mathrm{~d}, J 6.1 \mathrm{~Hz}, 3 \mathrm{H}, \mathrm{H} 1 ; 1.55-1.77, \mathrm{~m}, 4 \mathrm{H}, \mathrm{H} 3$ and $\mathrm{H} 4 ; 2.37-2.41, \mathrm{~m}, 2 \mathrm{H}, \mathrm{H} 9 ; 3.80-3.89, \mathrm{~m}, 1 \mathrm{H}, \mathrm{H} 5 ; 4.35-4.41, \mathrm{~m}, 2 \mathrm{H}, \mathrm{H} 2$ and $\mathrm{H} 8 ; 5.05-5.10$, m, $2 \mathrm{H}, \mathrm{H} 11 ; 5.78-5.87, \mathrm{~m}, 1 \mathrm{H}, \mathrm{H} 10 .{ }^{13} \mathrm{C}$ n.m.r. $\delta\left(100 \mathrm{MHz}, \mathrm{CDCl}_{3}\right)-5.0,-4.8,-4.5,-4.4, \mathrm{SiCH}_{3}$;

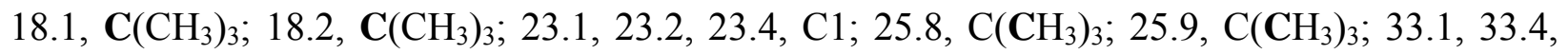
33.8, 33.9, C3; 34.4, 34.5, C4; 43.2, C9; 62.1, C5; 62.5, 62.8, C8; 68.1, 68.3, C2; 85.5, C6; 85.8, C7; 117.6, C11; 134.0, C10. MS: m/z (CI) $427\left(\mathrm{MH}^{+}, 24 \%\right) 217$ (100), 159 (64), 85 (75).

2-(tert-Butyldimethylsilyloxy)-8-(tert-butyldiphenylsilyloxy)undec-10-en-6-yn-5-one (25). 
Dess-Martin periodinane $^{16}(133 \mathrm{mg}, 0.32 \mathrm{mmol})$ was added to a mixture of alcohol $23(0.12 \mathrm{~g}$, $0.22 \mathrm{mmol})$ and pyridine $(0.2 \mathrm{~mL})$ in dichloromethane $(5 \mathrm{~mL})$ at room temperature. After $2 \mathrm{~h}$ the suspension was filtered through a short pad of Celite ${ }^{\mathrm{TM}}(1 \mathrm{~cm} \times 0.2 \mathrm{~cm})$ and the filtrate diluted with $\mathrm{NaOH}(1.3 \mathrm{M}, 5 \mathrm{~mL})$. The resultant mixture was extracted with dichloromethane $(3 \mathrm{x}$ $10 \mathrm{~mL}$ ) and the extracts dried over $\mathrm{MgSO}_{4}$ then concentrated at reduced pressure. Flash chromatography of the residue using 10\% diethyl ether - hexane as eluent afforded the title compound (25) (99 mg, 83\%) as colorless oil. (Found: $\mathrm{M}^{+\bullet}, 548.3102 . \mathrm{C}_{33} \mathrm{H}_{48} \mathrm{Si}_{2} \mathrm{O}_{3}$ requires $\mathrm{M}^{+\bullet}$, 548.3142). $v_{\max } 2958,1687,1471,1245,1091,836 \mathrm{~cm}^{-1} .{ }^{1} \mathrm{H} \mathrm{NMR}: \delta\left(400 \mathrm{MHz}, \mathrm{CDCl}_{3}\right) 0.03, \mathrm{~s}$, $3 \mathrm{H}, \mathrm{SiCH}_{3} ; 0.04, \mathrm{~s}, 3 \mathrm{H}, \mathrm{SiCH}_{3} ; 0.88, \mathrm{~s}, 9 \mathrm{H}, \mathrm{C}\left(\mathrm{CH}_{3}\right)_{3} ; 1.08, \mathrm{~s}, 9 \mathrm{H}, \mathrm{C}\left(\mathrm{CH}_{3}\right)_{3} ; 1.10, \mathrm{~d}, \mathrm{~J} 6.1 \mathrm{~Hz}, 3 \mathrm{H}$, $\mathrm{H} 1 ; 1.54-1.75, \mathrm{~m}, 2 \mathrm{H}, \mathrm{H} 3 ; 2.37-2.54, \mathrm{~m}, 4 \mathrm{H}, \mathrm{H} 4$ and $\mathrm{H} 9 ; 3.77-3.86, \mathrm{~m}, 1 \mathrm{H}, \mathrm{H} 2 ; 4.50, \mathrm{t}, J_{8,9} 6.1$, $1 \mathrm{H}, \mathrm{H} 8 ; 5.06-5.11, \mathrm{~m}, 2 \mathrm{H}, \mathrm{H} 11 ; 5.73-5.85, \mathrm{~m}, 1 \mathrm{H}, \mathrm{H} 10 ; 7.36-7.70, \mathrm{~m}, 10 \mathrm{H}, 2 \mathrm{x} \mathrm{Ar} .{ }^{13} \mathrm{C} \mathrm{NMR:} \delta$ $\left(100 \mathrm{MHz}, \mathrm{CDCl}_{3}\right)-4.8, \mathrm{SiCH}_{3} ;-4.4, \mathrm{SiCH}_{3} ; 18.0, \mathbf{C}\left(\mathrm{CH}_{3}\right)_{3} ; 19.3, \mathrm{C}\left(\mathrm{CH}_{3}\right)_{3} ; 23.6, \mathrm{C1} ; 25.8$, $\mathrm{C}\left(\mathrm{CH}_{3}\right)_{3} ; 26.8, \mathrm{C}\left(\mathrm{CH}_{3}\right)_{3} ; 33.1, \mathrm{C} 3 ; 41.4, \mathrm{C} 9 ; 42.1, \mathrm{C} 4 ; 63.4, \mathrm{C} 8 ; 67.2, \mathrm{C} 2 ; 83.9, \mathrm{C} 6 ; 91.9, \mathrm{C} 7$; 118.6, C11; 132.6, C10; 127.6-135.9, (Ar); 187.5, C5. MS: m/z 548 (M, 2\%), 491 (28), 450 (65), 359 (65), 281 (40), 197 (100), 73 (75).

2,8-Bis(tert-butyldimethylsilyloxy)undec-10-en-6-yn-5-one (26). Tetrapropylammonium perruthenate (16 mg, $0.0468 \mathrm{mmol}), N$-methylmorpholine- $N$-oxide $(0.16 \mathrm{~g}, 1.4 \mathrm{mmol})$, and $3 \AA$ molecular sieves $(0.47 \mathrm{~g})$ were added to a solution of alcohol 24 (400 $\mathrm{mg}, 0.94 \mathrm{mmol})$ in dichloromethane $(10 \mathrm{~mL})$. The mixture was stirred at room temperature for $30 \mathrm{~min}$ then filtered through a Celite ${ }^{\mathrm{TM}}$ pad and the solvent evaporated in vacuo. Flash chromatography of the residue using 10\% diethylether - hexane as eluent afforded the title compound 26 (385 mg, 98\%) as colorless oil. (Found: $\mathrm{MH}^{+\bullet}, 425.2907 . \mathrm{C}_{23} \mathrm{H}_{45} \mathrm{O}_{3} \mathrm{Si}_{2}$ requires $\mathrm{MH}^{+\bullet}, 425.2907$ ). $v_{\max } 2956,1682$, 1472, 1255, 1136, 1088, $836 \mathrm{~cm}^{-1} .{ }^{1} \mathrm{H}$ NMR: $\delta\left(400 \mathrm{MHz}, \mathrm{CDCl}_{3}\right)$ 0.01, 0.02, 0.03, 0.13, each s, $12 \mathrm{H}, \mathrm{SiCH}_{3} ; 0.87, \mathrm{~s}, 9 \mathrm{H}, \mathrm{C}\left(\mathrm{CH}_{3}\right)_{3} ; 0.89, \mathrm{~s}, 9 \mathrm{H}, \mathrm{C}\left(\mathrm{CH}_{3}\right)_{3} ; 1.12$, d, J 6.1 Hz, 3H, H1; 1.67-1.78, m, 4H, H3 and H9; 2.45, t, J 6.7 Hz, 2H, H4; 2.58-2.63, m, 2H, H9; 3.79-3.84, m, 1H, H2; 4.50, t, J $6.4 \mathrm{~Hz}, 1 \mathrm{H}, \mathrm{H} 8 ; 5.10-5.15, \mathrm{~m}, 2 \mathrm{H}, \mathrm{H} 11 ; 5.76-5.86, \mathrm{~m}, 1 \mathrm{H}, \mathrm{H} 10 .{ }^{13} \mathrm{C} \mathrm{NMR}: \delta\left(100 \mathrm{MHz}, \mathrm{CDCl}_{3}\right)$

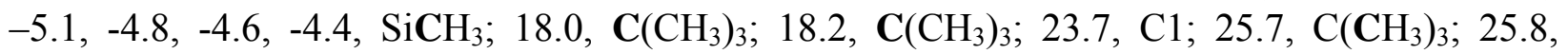
$\mathrm{C}\left(\mathrm{CH}_{3}\right)_{3} ; 33.2, \mathrm{C} 3 ; 41.9$, C9; 42.3, C4; 62.7, C2; 67.2, C8; 83.4, C6; 92.3, C7; 118.4, C11; 132.9, C10; 187.5, C5. MS: m/z (CI) $425\left(\mathrm{MH}^{+}, 60 \%\right), 293$ (40), 141 (38), 75 (100).

\section{8-(tert-Butyldimethylsilyloxy)-2-(tert-butyldiphenylsilyloxy)-10,11-epoxyundec-6-yn-5-one}

(27). Meta-chloroperoxybenzoic acid $(250 \mathrm{mg}, 1.46 \mathrm{mmol})$ was added with stirring to a mixture of ketone $(25)(200 \mathrm{mg}, 0.36 \mathrm{mmol})$ and sodium acetate $(0.12 \mathrm{~g}, 1.46 \mathrm{mmol})$ in dichloromethane $(20 \mathrm{~mL})$. The reaction mixture was stirred at room temperature for five days then quenched with water $(10 \mathrm{~mL})$. The organic layer was washed with brine $(2 \times 10 \mathrm{~mL})$, dried over $\mathrm{MgSO}_{4}$ and the solvent evaporated in vacuo. Flash chromatography of the residue using $20 \%$ diethyl ether hexane as eluent afforded the title compound (27) (160 mg, 79\%) as a colourless oil (Found: $\mathrm{MH}^{+\bullet}, 565.3183 . \mathrm{C}_{33} \mathrm{H}_{49} \mathrm{O}_{4} \mathrm{Si}_{2}$ requires $\left.\mathrm{MH}^{+\bullet}, 565.3169\right)$. IR: $v_{\max } 2930,2214,1681,1472,1428$, 1255, 1120, $836 \mathrm{~cm}^{-1} .{ }^{1} \mathrm{H}$ NMR: $\delta\left(400 \mathrm{MHz}, \mathrm{CDCl}_{3}\right)$ 0.02, s, $3 \mathrm{H}, \mathrm{SiCH}_{3} ; 0.03, \mathrm{~s}, 3 \mathrm{H}, \mathrm{SiCH}_{3}$; 0.88 , s, 9H, C(CH $)$; 1.08, s, 9H, C(CH $\left.\mathrm{CH}_{3}\right) ; 1.09$, d, J 6.1 Hz, 3H, H1; 1.59-1.71, m, 2H, H3; 1.901.99, m, 2H, H9; 2.36-2.47, m, 1H, H11a; 2.36-2.47, m, 2H, H4; 2.72-2.79, m, 1H, H11b; 3.083.17, m, 1H, H10; 3.75-3.79, m, 1H, H2; 4.67-4.71, m, 1H, H8; 7.37-7.73, m, 10H, $2 \times \mathrm{Ph} .{ }^{13} \mathrm{C}$ NMR (100 MHz, $\left.\mathrm{CDCl}_{3}\right): \delta 4.8, \mathrm{SiCH}_{3},-4.5, \mathrm{SiCH}_{3}, 18.0, \mathrm{C}\left(\mathrm{CH}_{3}\right) ; 19.2, \mathrm{C}\left(\mathrm{CH}_{3}\right) ; 23.6, \mathrm{C} 1$ $\left(\mathrm{CH}_{3}\right)$; 25.8, $\mathrm{C}\left(\mathrm{CH}_{3}\right)$; 26.8, $\mathrm{C}\left(\mathrm{CH}_{3}\right)$; 32.9, C3; 40.9, C9; 40.9, 41.0, 41.2, 41.3, C11; 47.3, C4; 
48.6, C10; 61.5, C8, 67.2, C2; 84.2, C6; 90.9, C7; 127.2-135.4, Ar; 187.2, C5. MS: m/z (CI) 565 $\left(\mathrm{MH}^{+}, 5 \%\right), 195$ (35), $135(68), 73$ (100).

2,8-Bis(tert-butyldimethylsilyloxy)-10,11-epoxyundec-6-yn-5-one (28). Metachloroperoxybenzoic acid $(170 \mathrm{mg}, 0.99 \mathrm{mmol})$ was added with stirring to a mixture of ketone 26 (70 $\mathrm{mg}, 0.16 \mathrm{mmol})$ and sodium acetate $(81 \mathrm{mg}, 0.99 \mathrm{mmol})$ in dichloromethane $(20 \mathrm{~mL})$. The reaction mixture was stirred at room temperature for five days then quenched with water $(10 \mathrm{ml})$. The organic layer was washed with brine $(2 \times 10 \mathrm{~mL})$, dried over $\mathrm{MgSO}_{4}$ and the solvent evaporated in vacuo. Flash chromatography of the residue using $50 \%$ diethyl ether hexane as eluent afforded the title compound $28(55 \mathrm{mg}, 75 \%)$ as colorless oil (Found: $\mathrm{MH}^{+\bullet}$, 441.2284. $\mathrm{C}_{23} \mathrm{H}_{45} \mathrm{O}_{4} \mathrm{Si}_{2}$ requires, $\mathrm{MH}^{+\bullet}$, 441.2856). $v_{\max } 2929,1682,1472,1255,1097,837 \mathrm{~cm}^{-1}$. ${ }^{1} \mathrm{H}$ NMR $\left(400 \mathrm{MHz}_{\mathrm{CDCl}}\right): \delta 0.12,0.14,0.15,0.17$, each s, $12 \mathrm{H}, \mathrm{SiCH}_{3} ; 0.86, \mathrm{~s}, 9 \mathrm{H}, \mathrm{C}\left(\mathrm{CH}_{3}\right)$; $0.90, \mathrm{~s}, 9 \mathrm{H}, \mathrm{C}\left(\mathrm{CH}_{3}\right) ; 1.10$, d, J $6.0 \mathrm{~Hz}, 3 \mathrm{H}, \mathrm{H} 1 ; 1.66-1.78, \mathrm{~m}, 2 \mathrm{H}, \mathrm{H} 3 ; 1.91-1.96, \mathrm{~m}, 2 \mathrm{H}, \mathrm{H} 9$; 2.49-2.55, m, 2H, H4; 2.62-2.65, m, 1H, H11a; 2.77-2.80, m, 1H, H11b; 3.06-3.09, m, 1H, H10; 3.78-3.86, m, 1H, H2; 4.68-4.71, m, 1H, H8. ${ }^{13} \mathrm{C}$ NMR $\left(100 \mathrm{MHz}, \mathrm{CDCl}_{3}\right): \delta-5.2,-4.9$, -4.6, 4.4, $\mathrm{SiCH}_{3} ; 18.0, \mathbf{C}\left(\mathrm{CH}_{3}\right) ; 18.1, \mathbf{C}\left(\mathrm{CH}_{3}\right) ; 23.7, \mathrm{C} 1 ; 25.5, \mathrm{C}\left(\mathrm{CH}_{3}\right) ; 25.7, \mathrm{C}\left(\mathrm{CH}_{3}\right) ; 33.1, \mathrm{C} 3 ; 41.1$, 41.2, C9; 41.5, C4; 46.7, 47.5, C11; 48.6, C10; 60.3, 60.8, C8; 67.2, C2; 83.3, 83.8, C6; 91.3, 91.8, C7; 187.3, C5. MS: m/z (CI) $441\left(\mathrm{MH}^{+}, 100 \%\right), 309$ (70), 92 (40), 74 (82).

\section{8-(tert-Butyldiphenylsilyloxy)-2-(tert-butyldimethylsilyloxy)-10,11-epoxyundecan-5-one}

(10). Sodium bicarbonate $(50 \mathrm{mg}, 0.57 \mathrm{mmol})$ and $10 \%$ palladium on charcoal $(5 \mathrm{mg})$ were added to a solution of epoxide $27(160 \mathrm{mg}, 0.29 \mathrm{mmol})$ in ethyl acetate $(10 \mathrm{~mL})$. The reaction mixture was stirred at room temperature under a hydrogen atmosphere. After $2 \mathrm{~h}$ the suspension was filtered through a short pad of Celite ${ }^{\mathrm{TM}}$ and the solvent removed under reduced pressure. Flash chromatography using 50\% diethyl ether - hexane as eluent afforded the title compound 10 (160 mg, 98\%) as colorless oil (Found: $\mathrm{MH}^{+\bullet}, 569.3471 . \mathrm{C}_{33} \mathrm{H}_{53} \mathrm{O}_{4} \mathrm{Si}_{2}$ requires, $\mathrm{MH}^{+\bullet}, 569.3482$ ). IR: $v_{\max } 2929,1714,1427,1256,1111 \mathrm{~cm}^{-1} .{ }^{1} \mathrm{H}$ NMR $\left(400 \mathrm{MHz}, \mathrm{CDCl}_{3}\right): \delta 0.01, \mathrm{~s}, 3 \mathrm{H}, \mathrm{SiCH}_{3}$; 0.03, s, 3H, $\mathrm{SiCH}_{3} ; 0.88$, s, 9H, C(CH $)_{3} ; 1.03-1.08, \mathrm{~s}, 9 \mathrm{H}, \mathrm{C}\left(\mathrm{CH}_{3}\right)_{3} ; 1.09, \mathrm{~d}, J 6.2 \mathrm{~Hz}, 3 \mathrm{H}, \mathrm{H} 1$; 1.51-1.60, m, 2H, H3; 1.61-1.86, m, 2H, H7; 1.61-1.86, m, 2H, H9; 2.26-2.40, m, 4H, H4 and H6; 2.26-2.40, m, 1H, H11a; 2.61-2.65, m, 1H, H11b; 2.84-2.95, m, 1H, H10; 3.74-3.81, m, 1H, $\mathrm{H} 2$; 3.93-3.99, m, 1H, H8; 6.94-7.22, m, 10H, Ph. ${ }^{13} \mathrm{C}$ NMR (100 MHz, $\left.\mathrm{CDCl}_{3}\right): \delta-4.8, \mathrm{SiCH}_{3}$; -

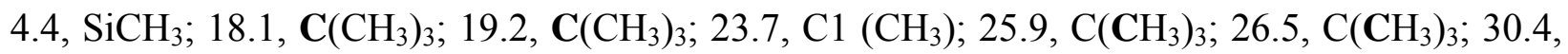
30.7, C9; 33.1, C3 and C7; 37.9, 38.7, 39.4, 39.9, C4 and C6; 46.8, 47.2, C11; 49.0, 49.4, C10; 67.2, C2; 70.5, 70.8, C8; 127.6-135.8, Ph; 210.6, C5. MS: m/z (CI) 568 (M, 0.16\%), 379 (94), 255 (100), 199 (93), 75 (89).

2,8-Bis(tert-butyldimethylsilyloxy)-10,11-epoxyundecan-5-one (11). Sodium bicarbonate $(21 \mathrm{mg}, 0.25 \mathrm{mmol})$, and palladium on charcoal $(2 \mathrm{mg})$ were added to a solution of epoxide 28 $(50 \mathrm{mg}, 0.12 \mathrm{mmol})$ in ethyl acetate $(10 \mathrm{~mL})$. The reaction mixture was stirred at room temperature under a hydrogen atmosphere. After $2 \mathrm{~h}$ the suspension was filtered through a short pad of Celite ${ }^{\mathrm{TM}}$, and the solvent removed under reduced pressure. Flash chromatography using $50 \%$ diethylether - hexane as eluent afforded the title compound 11 (41 mg, 74\%) as colorless oil. (Found: $\mathrm{MH}^{+\bullet}, 445.3180 . \mathrm{C}_{23} \mathrm{H}_{49} \mathrm{O}_{4} \mathrm{Si}_{2}$ requires, $\mathrm{MH}^{+\bullet}$, 445.3169). IR: $v_{\max } 2929,1716,1472$, 1236, 1072, $836 \mathrm{~cm}^{-1} .{ }^{1} \mathrm{H}$ NMR $\left(400 \mathrm{MHz} \mathrm{CDCl}_{3}\right): \delta-0.02,-0.03,0.01,0.05$, each s, $12 \mathrm{H}$, $\mathrm{SiCH}_{3} ; 0.86$, s, 9H, C(CH $)_{3} ; 0.87, \mathrm{~s}, 9 \mathrm{H}, \mathrm{C}\left(\mathrm{CH}_{3}\right)_{3} ; 1.10, \mathrm{~d}, \mathrm{~J} 6.0 \mathrm{~Hz}, 3 \mathrm{H}, \mathrm{H1} ; 1.61-1.69, \mathrm{~m}, 4 \mathrm{H}$, $\mathrm{H} 3$ and H7; 1.71-1.75, m, 2H, H9; 2.41-2.53, m, 1H, H11a; 2.71-2.77, m, 1H, H11b; 2.95-3.03, 
m, 1H, H10; 3.77-3.84, m, 1H, H2; 3.87-3.96, m, 1H, H8. $\left.{ }^{13} \mathrm{C} \mathrm{NMR} \mathrm{(100} \mathrm{MHz,} \mathrm{CDCl}_{3}\right): \delta-4.77$,

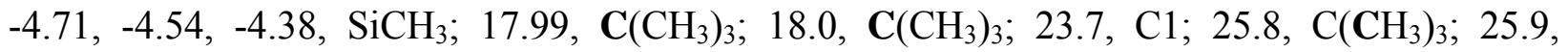
$\mathrm{C}\left(\mathrm{CH}_{3}\right)_{3} ; 30.6,31.2, \mathrm{C} 9 ; 33.2, \mathrm{C} 3$ and $\mathrm{C} 7 ; 37.8,38.3,38.8, \mathrm{C} 4 ; 40.1,40.2, \mathrm{C} 6$; 46.8, 47.6, $\mathrm{C} 11$; 49.2, 49.6, C10; 67.5, C2; 69.1, 69.3, C8; 210.7, C5. MS: m/z (CI) $445\left(\mathrm{MH}^{+}, 65 \%\right), 313$ (73), 255 (100), 181 (90), 75 (58).

1-(2-Methoxy-5-methyltetrahydrofuran-2-yl)hex-5-en-1-yn-3-ol (29). Camphorsulfonic acid (12 $\mathrm{mg}, 0.047 \mathrm{mmol}$ ) was added to a solution of ketone 26 (100 mg, $0.236 \mathrm{mmol})$ in methanol $(10 \mathrm{~mL})$ and the mixture stirred at room temperature for $2 \mathrm{~h}$. The methanol was removed under reduced pressure and the organic residue washed with water $(2 \times 2 \mathrm{~mL})$ and brine $(2 \times 1 \mathrm{~mL})$ then extracted with diethyl ether $(5 \mathrm{~mL})$. The organic extract was dried $\left(\mathrm{MgSO}_{4}\right)$, concentrated under reduced pressure and further purification of the residue by flash chromatography using 50\% diethyl ether - hexane as eluent afforded the title compound 29 (491 mg, 97\%) as a colorless oil. (Found: $\mathrm{MH}^{+\bullet}, 211.1335 . \mathrm{C}_{12} \mathrm{H}_{19} \mathrm{O}_{3}$ requires $\left.\mathrm{MH}^{+\bullet}, 211.1334\right)$. v $v_{\max } 3429,2973,1444,1381$, 1315, 1235, 1145, 1089, 1048, $916 \mathrm{~cm}^{-1} .{ }^{1} \mathrm{H}$ NMR (400 MHz, $\mathrm{CDCl}_{3}$ ): $\delta 1.29$, d, J $6.2 \mathrm{~Hz}, 3 \mathrm{H}$, $\mathrm{CH}_{3}$; 1.51-1.70, m, 2H, H4'; 2.15-2.21, m, 2H, H3'; 2.47-2.51, m, 2H, H4; 3.35, 3.36, 3.37, 3.38, $\mathrm{s}, 3 \mathrm{H}, \mathrm{OCH}_{3}$; 4.14-4.22, m, 1H, H5'; 4.31-4.39, m, 1H, H3; 4.48, s, 1H, OH; 5.16-5.26, m, 2H, H6; 5.85-5.92, m, 1H, H5. ${ }^{13} \mathrm{C}$ NMR (100 MHz, $\left.\mathrm{CDCl}_{3}\right): \delta 22.4, \mathrm{CH}_{3} ; 31.5,31.8, \mathrm{C} 4$ '; 40.0, 40.1, C3'; 41.8, C4; 61.4, $\mathrm{OCH}_{3} ; 75.3, \mathrm{C} 3 ; 77.7, \mathrm{C} 5$ '; 82.0, C1; 84.5, 84.7, C2; 101.5, 101.8, C2'; 118.9, C6; 132.9, C5. MS: m/z (CI) 211 (MH+, 6\%), 179 (100), 169 (40), 137 (38), 91 (25).

5,6-Epoxy-1-(2-methoxy-5-methyltetrahydrofuran-2-yl)hex-1-yn-3-ol $\quad$ (30). Metachloroperoxybenzoic acid $(450 \mathrm{mg}, 2.6 \mathrm{mmol})$ was added with stirring to a mixture of methyl acetal $29(270 \mathrm{mg}, 1.3 \mathrm{mmol})$ and sodium acetate $(210 \mathrm{mg}, 2.6 \mathrm{mmol})$ in dichloromethane $(20 \mathrm{ml})$. The reaction mixture was stirred at room temperature for two days then quenched with water $(10 \mathrm{~mL})$. The organic layer was washed with brine $(2 \times 5 \mathrm{~mL})$, dried over $\mathrm{MgSO}_{4}$, and the solvent evaporated in vacuo. Flash chromatography of the residue using $50 \%$ diethyl ether hexane as eluent afforded the title compound $30(260 \mathrm{mg}, 89 \%)$ as a colorless oil. (HRMS: $\mathrm{M}^{+\bullet}$ OMe, 195.1012. $\mathrm{C}_{11} \mathrm{H}_{18} \mathrm{O}_{4}$ requires $\mathrm{M}^{+\bullet}$-OMe, 195.1021). IR: $v_{\max } 3429,2973,1444,1381,1315$, 1235, 1145, 1089, 1048, $916 \mathrm{~cm}^{-1} .{ }^{1} \mathrm{H}$ NMR (400 MHz, $\left.\mathrm{CDCl}_{3}\right): \delta 1.29, \mathrm{~d}, J 6.2 \mathrm{~Hz}, 3 \mathrm{H}, \mathrm{CH}_{3}$; 1.57-1.70, m, 2H, H4'; 2.15-2.21, m, 2H, H3'; 2.22-2.29, m, 2H, H4; 2.55-2.61, m, 1H, H6a; 2.80-2.85, m, 1H, H6b; 3.10-3.20, m, 1H, H5; 3.35, 3.36, s, 3H, OCH 3 ; 4.14-4.22, m, 1H, H5'; 4.66-4.70, m, 1H, H3. ${ }^{13} \mathrm{C}$ NMR $\left(100 \mathrm{MHz}, \mathrm{CDCl}_{3}\right): \delta 20.9, \mathrm{CH}_{3} ; 31.6,31.8, \mathrm{C} 4$ '; 39.9, 40.1, C3'; 41.1, C4; 46.9, C6; 49.1, C5; 60.0, 60.3, $\mathrm{OCH}_{3} ; 75.4, \mathrm{C} 3 ; 77.2, \mathrm{C} 5$ '; 77.9, C1; 80.0, C2; 103.9, C2'. MS: m/z (CI) $195\left(\mathrm{M}-\mathrm{OCH}_{3}, 100 \%\right), 137$ (40), 55 (68), 43 (72), 41 (94).

2-(2,3-Epoxyprop-1-yl)-7-methyl-1,6-dioxaspiro[4.4]nonane (9). Sodium bicarbonate (24 mg, $0.17 \mathrm{mmol})$ and $10 \%$ palladium on charcoal $(2 \mathrm{mg})$ were added to a solution of epoxide 30 $(20 \mathrm{mg}, 0.090 \mathrm{mmol})$ in ethyl acetate $(10 \mathrm{~mL})$. The reaction mixture was stirred at room temperature under a hydrogen atmosphere. After $2 \mathrm{~h}$ the suspension was filtered through a short pad of Celite ${ }^{\mathrm{TM}}$ and the solvent removed under reduced pressure. Flash chromatography using $50 \%$ diethyl ether - hexane as eluent afforded the title compound 9 (11 mg, 63\%) as a colorless oil. HRMS: Found: $\mathrm{M}^{+\bullet}-\mathrm{H}, 197.3122 . \mathrm{C}_{11} \mathrm{H}_{18} \mathrm{O}_{3}$ requires, $\mathrm{M}^{+\bullet}-\mathrm{H}$ 197.3145). IR: $v_{\max } 2973,1646$, 1458, 1378, 1078, $861 \mathrm{~cm}^{-1}$. ${ }^{1} \mathrm{H}$ NMR (400 MHz, $\left.\mathrm{CDCl}_{3}\right): \delta 1.28, \mathrm{~d}, J 6.3 \mathrm{~Hz}, 3 \mathrm{H}, \mathrm{CH}_{3}$; $1.57-$ 1.70, m, 4H, H3 and H8; 2.03-2.10, m, 2H, H1'; 2.15-2.21, m, 4H, H4 and H9; 2.49-2.52, m, 1H, H3'b; 2.75-2.82, m, 1H, H3'a; 3.00-3.10, m 1H, H2'; 3.61-3.89, m, 1H, H7; 4.13-4.36, m, 1H, 
H2. ${ }^{13} \mathrm{C}$ NMR $\left(100 \mathrm{MHz}, \mathrm{CDCl}_{3}\right): \delta 21.1,21.3, \mathrm{CH}_{3} ; 30.5,31.6,31.9, \mathrm{C} 8 ; 32.2,32.6, \mathrm{C} 3 ; 35.1$, 35.4, C4; 36.0, 36.2, 36.7, C9; 40.7, C1'; 47.4, 47.5, C3'; 49.5, 49.7, 49.8, 49.9, C2'; 73.9, 74.2, C2; 75.9, 76.1, C7; 102.9, 103.9, C5. MS: m/z (CI) 197 (M-H, 7\%), 43 (100).

\section{References}

1. Blaser, M. J. Clin. Infect. Dis. 1992, 15, 386.

2. Walsh, J. H.; Peterson, W. L. New England Journal of Medicine 1995, 333, 984.

3. Dekker, K. A.; Inagaki, T.; Gootz, T. D.; Kanede, K.; Nomura, E.; Sakakibara, T.; Sakemi, S.; Sugie, Y.; Yamauchi, Y.; Yoshikawa, N.; Kojima, N. J. Antibiot. 1997, 50, 833.

4. Arnone, A.; Assante, G.; Nasini, G.; Vajna de Pava, O. Phytochemistry 1990, 29, 613.

5. Chen, Z. X.; He, B. M. Japanese Patent 7-285,862, 1995.

6. Perkins, M. V.; Kitching, W.; Drew, R. A. I.; Moore, C. J.; Konig, W. A. J. Chem. Soc., Perkin Trans. 1 1990, 1111.

7. Naya, Y.; Kotake, M. Tetrahedron Lett. 1967, 18, 1715.

8. MacInnes, I.; Walton, J. C. J. Chem. Soc., Perkin Trans. 2 1987, 1077.

9. Malacria, M.; Journet, M. J. Org. Chem. 1992, 57, 3085.

10. Capella, L.; Montevecchi, P. C. Tetrahedron Lett. 1994, 35, 8445.

11. Kucklaender, U.; Edoho, E. J.; Rinus, O.; Masser, W. Chem. Ber. 1980, 113, 3405.

12. Li, C. H.; Yieh, Y. H.; Lin, Y.; Lu, Y. J.; Chi, A. H.; Hsing, C. Y. Tetrahedron Lett. 1981, 22, 3467.

13. Yamada, S. J. Org. Chem. 1992, 57, 1591.

14. Kalivretenos, A.; Stille, J. K.; Hegedus, L. S. J. Org. Chem. 1991, 56, 2883.

15. Sugai, T.; Katoh, O.; Ohta, H. Tetrahedron 1995, 51, 11987.

16. Dess, D. B.; Martin, J. C. J. Org. Chem. 1991, 113, 7277.

17. Schlosser, M. Pure and Applied Chem. 1988, 60, 1627.

18. Taylor, S. K.; Atkinson, R. F.; Almli, E. P.; Carr, M. D.; Van Huis, T. J. Whittaker, M. R. Tetrahedron: Asymmetry 1995, 6, 157.

19. Nakai, T.; Tomioka, K. Pure Appl. Chem. 1997, 69, 595.

20. Hoppe, D.; Hense, T. Angew. Chem. Int. Ed. 1997, 36, 2282.

21. Xavier, F.; Figadere, B.; Cave, A. Tetrahedron Lett. 1995, 36, 711.

22. Duan, M.; Paquette, L. Tetrahedron Lett. 2000, 41, 3789.

23. Smith, A. B.; Ott, G. R. J. Am. Chem. Soc. 1998, 120, 3935.

24. Gross, A.; Fensterbank, L.; Bogen, S.; Thouvenot, R.; Malacria, M. Tetrahedron, 1995, 53, 13797. 